\title{
Behavioural Factors as Determinants of Effective Budgeting Process in Public Secondary Schools
}

\author{
L.Z. Radebe \\ Department of Accountancy, Vaal University of Technology, \\ Vanderbijlpark, Republic of South Africa \\ lizzie@vut.ac.za \\ Dr. P.Q. Radebe \\ Department of Human Resources Management, Vaal University of Technology \\ Vanderbijpark, Republic of South Africa \\ patrick@vut.ac.za
}

Doi:10.5901/mjss.2014.v5n23p205

\section{Abstract}

\begin{abstract}
A budget is an action plan that is utilized by organisations, private or public, in order to attain their objectives. Budgets are used to ensure better financial performance for organisations. Public secondary schools also prepare their budgets to plan for their income and expenditure. The purpose of the study was to identify the behavioural factors essential for an effective budgeting process in public secondary schools in Gauteng South, South Africa. To achieve this objective a structured questionnaire with two sections, $A$ and $B$ was developed. Section $A$ of the questionnaire aimed to gather biographical information about the respondents, whereas Section $B$ dealt with key issues pertaining to the budgeting process. The reliability of the questionnaire was tested using Cronbach's alpha coefficient. The feedback from the questionnaire was analysed by means of Exploratory Factor Analysis through which five factors were extracted and their reliability also tested. The factor loading matrix was computed to identify appropriate items for each factor. The findings from the study indicated that for effective budgeting process to occur in public secondary schools the following behavioural factors should be embedded in the process: participation and budget control, budget planning, motivation, training and development, including co-ordination and communication.
\end{abstract}

Keywords: budget control; budget planning; training and development; communication; co-ordination; motivation.

\section{Introduction}

A budget is an action plan through which organisations, private or public, are able to reach their strategic objectives (Luecke, 2002). Globally, managers in organisations are required to make budgets in order to allow them to reach the strategic goals of organisations. It is through these budgets that managers and subordinates are able to ensure acceptable performances in organisations. Budgets should therefore assist managers to identify unfavourable variances and take corrective actions (Horngren, Sundem \& Stratton, 2002).

Public secondary schools prepare their budgets to plan for the income and expenditure. Schools' budgets should be prepared to help with financial plans of activities scheduled to take place during the academic year in order to realise their mission and vision. A budget could assist by providing information about real and projected income and expenditure, and is used as a control mechanism to monitor whether schools adhere to the planned budget (Dinako Management Consultants, 2004).

\section{Literature Review}

Du Toit, Neuland, Oost, and Begemann (2001:70) define a budget as a "detailed plan which sets out, in moneyterms, the plans for income and expenditure in respect of a future period of a time." Creating a budget requires a consideration of behavioural factors that serve as preconditions for effective budgeting (Magner, Johnson, Little, Staley \& Welker, 2006). These behavioural factors entail budget planning, co-ordination of budget activities during the budgeting process, communication, motivation, employee participation, and budget control (James, 2006). In light of the aforementioned the 
discussion on the budgeting process in this paper is behaviourist in approach and not quantitative. The concepts, behavioural factors and budgeting activities, were used interchangeably throughout the paper.

\subsection{Budget planning}

Drudy (2001:279) defines planning as "the design of a desired future and an effective way of bringing it about." Planning is an effective tool for good management in all types of organisations which commences with the formulation of a mission statement and corporate objectives (Weetman, 2003). In this respect, Fruitticher, Stroud, Laster and Yakhou (2005) warn that if an organisation's goal as well as its objectives are not formulated it will be inconceivable for all budget participants to determine the effectiveness of income expenditure.

\subsection{Co-ordinating budget activities}

Co-ordination is the establishment of the framework in which budget activities are to be performed. Co-ordination refers to the systematisation of interdependent parts into one unit. Co-ordination requires bringing the many functional units of an organisation into a co-ordinated structure and assigning authority and responsibility to individuals (Vigario, 2005). The implementation of budget structures and processes should be based on integrity, openness, consistency, fairness and a professional approach (Weetman, 2003). Co-ordination of budget activities is an effort to motivate employees to work together for the good of the organisation (Luecke, 2002).

\subsection{Employee participation in the budgeting process}

Participation in the budgeting process is twofold. On the one hand employees take part in reviewing budget options. On the other hand employees play a role in deciding on the preferred budget option (Lucey, 2002). A participative approach to the budgeting process, known as self-imposed budgeting, allows the involvement of all stakeholders in developing a budget (Garrison \& Noreen, 2003). During this activity tough negotiations ensue to arrive at the most beneficial budget. The negotiation should be characterized by openness and fairness in order to allay suspicions and uncertainties commonly associated with a budgeting process (Drudy, 2001).

\subsection{Communication of budget plans}

Effective budgeting process requires communication of budget plans which further enhances the effectiveness with which the budgeting process is implemented. Setting out the strategy should involve all senior managers from the various functions. The leading and lagging indicators in respect of budget plans are identified through an ongoing communication among budget holders after which they should be communicated to all employees and stakeholders in an organisation (Hansen \& Mowen, 2000). On the whole, the communication process is a vital part of creating a sense of teamwork and ensuring that all key players understand the role they play in achieving budget targets (Weetman, 2003).

\subsection{Motivation of employees}

Budget targets that are set during the budget planning should not be unrealistically high or low as this will only lead to low motivation or may allow too much slack. If budget targets leave room for slack waste will occur. For this reason setting budget targets require participation of stakeholders (Drudy, 2002). Vigario (2005) asserts that if a budget is to be successful, it must have the complete acceptance and support employees. If lower or middle management personnel sense that top management is negative about budgeting or if top management simply tolerates budgeting as a necessary evil, then their own attitude will reflect a similar lack of enthusiasm.

\subsection{The budget control}

Dyson (2004) describes the budget control process as comparing the actual budget against the planned budget after which corrective actions are taken if significant variances occur. Conversely, corrective actions are not required if the evaluation shows that the actual results match with the budgeted results or a variance amount is favourable (Hansen \& Mowen, 2000). The budget control is carried out to improve financial accountability of budget holders and financial sustainability of organisations (Yuen, 2006). 
Before corrective actions can be taken on unfavourable variances an investigation should be conducted to find out the causes for such variances. Furthermore, significant variances should be reported and acted upon (Andrews 2004).

\subsection{Training and development of employees}

Scott (2001) opines that budgeting can be effectively implemented when role players in the budgeting process have financial skills. For this reason, individuals playing a role in the budgeting process should undergo some skills development in financial management so that they are fully conversant with the relevance and importance of budgeting and budgetary control system. Empowering role players with financial skills has the following potential benefits: it helps them to take more control over their jobs and working environment, and enhances the contribution they make as individuals and members of a team. Empowering those that participate in the budgeting process offers them the authority and the responsibility for decision making, and closes a decision loop thereby making them accountable for their decisions (De Waal 2005).

\section{Problem Statement}

Whilst private organisations draw up budgets in order to maximise profits, non-profit organisations like public schools utilise budgets to plan and control current expenditure (Moore, 1999). The authors, Van Rensburg, Ambe, Evangelou, Govender, Koortzen and Ziemerink (2008) state that in non-profit organisations the emphasis is only on the control of current expenditure. Budgets that focus only on control of expenditure and ignore salient behavioural factors encourage inefficiency and waste (Garrison \& Noreen, 2003). In addition, the exclusive focus on expenditure generates a neglect of objectives of an organisation (McLeary, 1999). To aggravate matters, non-profit organisations do not have financial considerations at the top of their priority list (Hansen \& Mowen, 2000).

Public secondary schools generate and obtain their income by raising funds, receiving donations, renting their facilities to the public, charging parents a fee (school fees) and receiving grants from the government. The report of auditors generally indicates that these allocated funds are not efficiently spent in various public secondary schools (Dinako Management Consultants, 2004).

If public secondary schools can effectively implement the budgeting process, they can achieve greater success in meeting their primary aims. They can, through proper planning and controlling of budgets, improve their efficiency and effectiveness (Hassen, 2011). The purpose of the study is, therefore, to identify the behavioural factors that are essential for effective budgeting process in public secondary schools.

\section{The Purpose of the Study}

The primary objective of this study is to identify the behavioural factors that are necessary for effective budgeting process in public secondary schools in Gauteng South, South Africa.

\section{Population and Sample}

The target population for this study is public secondary schools in the Gauteng South. Cluster sampling as one type of probability sampling method was utilized to draw the schools from towns and townships. From the selected clusters, schools were randomly selected (Manoharan, 2010). In each of the selected schools all of the educators were chosen to be part of the study.

Gauteng South constituted of 63 public secondary schools. The total number of principals, deputy-principals, heads of department and educators in all of these schools was 2 479. Leedy and Ormrod's (2010) advice is that when the population size is around $1500,20 \%$ of the population should be sampled to be the units of analysis. In this study the total population is 2 479. Following Leedy and Ormrod's guideline the sample size for this study should be 466 units of analysis. In this study 496 questionnaires were completed and returned, thereby exceeding Leedy and Ormrod's sampling threshold.

\section{Instrumentation}

Data was collected by means of a survey using a self-administered structured questionnaire. The questionnaire utilised in this study consisted of two sections, Section A and Section B. Section A sought to elicit biographical information relating 
to the geographical location of schools, the position held by respondents at participating schools, whether or not participants belonged to the finance committee, the number of years in service of respondents, the number of learners and educators in participating schools. The questions in this section were close-ended. Section B of the questionnaire was a four-Likert scale questionnaire with four statements about the budgeting process. Respondents were expected to indicate the degree to which they "Strongly agree", "Agree", "Do not agree" and "Strongly disagree" with each statement provided.

The internal reliability of a research instrument was measured by means of Cronbach's alpha coefficient. Cronbach's alpha for the questionnaire used in the study was .975. This was an indication that the research instrument in this study was highly reliable. The reliability of factors derived from section B of the questionnaire was also tested. The reliability scores of each factor and the overall reliability score are shown in table 1.

Table 1: Reliability values of the factors

\begin{tabular}{|l|c|}
\hline Factors extracted from the questionnaire & Cronbach's alpha values \\
\hline Factor 1: Participation and budget control & .977 \\
\hline Factor 2: Budget planning & .924 \\
\hline Factor3: Motivation & .891 \\
\hline Factor 4: Training and development & .898 \\
\hline Factor 5: Co-ordination and communication & .740 \\
\hline Overall scale reliability & .975 \\
\hline
\end{tabular}

Table 1 illustrates that the factors extracted from the items in the questionnaire were reliable as they each had Cronbach's alpha value above .70 and the overall Cronbach's alpha value was .975 .

\section{Results and Discussion}

\subsection{Descriptive statistics}

Feedback on Section A of the questionnaire, which represented the biographical information, is presented in table 2.

Table 2: Demographic information

\begin{tabular}{|c|c|c|c|}
\hline Variable & $N$ & Categories & $\%$ \\
\hline District & 496 & $\begin{array}{l}\text { D7 } \\
\text { D8 }\end{array}$ & $\begin{array}{l}30 \\
70\end{array}$ \\
\hline Position & 496 & $\begin{array}{c}\text { Educator } \\
\text { HOD } \\
\text { Deputy principal } \\
\text { Principal }\end{array}$ & $\begin{array}{c}79 \\
13 \\
3 \\
5\end{array}$ \\
\hline School finance committee & 496 & $\begin{array}{c}\text { Member } \\
\text { Non-member }\end{array}$ & $\begin{array}{l}10 \\
90 \\
\end{array}$ \\
\hline Years in service & 496 & $\begin{array}{c}<5 \text { years } \\
6-10 \text { years } \\
11-15 \text { years } \\
16-20 \text { years } \\
>20 \text { years }\end{array}$ & $\begin{array}{c}21 \\
31 \\
19 \\
9 \\
20 \\
\end{array}$ \\
\hline Number of learners per school & 496 & $\begin{array}{c}<500 \\
500-5000 \\
>1000\end{array}$ & $\begin{array}{c}1 \\
58 \\
41\end{array}$ \\
\hline Number of educators per school & 496 & $\begin{array}{c}<20 \\
20-49 \\
>50\end{array}$ & $\begin{array}{c}1 \\
15 \\
84\end{array}$ \\
\hline
\end{tabular}

Table 2 shows that a lot of respondents were from the D8 making up 70\% of the total number of respondents, while participants from D7 constituted only 30\% of total number of respondents. Many respondents (79\%) to the questionnaire were educators, whereas $13 \%$ respondents were heads of departments. The percentages of deputy-principals and 
principals in the study were 3\% and 5\% respectively. Table 2 further indicates that many of the experienced educators, with a term of service of more than five years, took part in the study.

Many of the respondents to (90\%) the questionnaire were not members of the school finance committee. Most of the schools (58\%) that were involved in the study had about 500-1000 learners per school. The schools with learners more than 1000 per school made up $41 \%$ of the responding schools and only $1 \%$ of schools who participated in the study had less than 500 learners per school. Lastly, substantial number of the schools (84\%) participating in the study had more than 50 educators per school.

\subsection{Exploratory factor analysis}

Exploratory factor analysis (EFA) was used to analyse data. Before the use of the factor analysis the Kaiser-Meyer Olkin (KMO) and Barlett's tests of sphericity were conducted to measure the reliability of items. The tests also determined the suitability of factor analysis for the data set in the study (Lombaard,Van der Merwe, Kele \& Mouton,2011). The golden rule is that if the values resulting from the KMO test are between 0.5 and close to 1.0 the factor analysis is firmly deemed to be suitable for the study (Williams, Onsman \& Brown, 2010).

Table 3: Bartlett's test of Sphericity and the KMO index

\begin{tabular}{|l|c|c|}
\hline \multicolumn{2}{|c|}{ Kaiser-Meyer-Olkin Measure of Sampling Adequacy. } & .944 \\
\hline \multirow{3}{*}{ Bartlett's Test of Sphericity } & Approx. Chi-Square & 5275.533 \\
\cline { 2 - 3 } & Df & 496 \\
\cline { 2 - 3 } & Sig. & .000 \\
\hline
\end{tabular}

In essence, where variables, in this case the questionnaire statements, show no sign of being related, the factor analysis would be considered unsuitable. Conversely, if variables are related factor analysis would be deemed appropriate for the study. In this study the recorded chi-square value resulting from the use of Bartlett's test of sphericity is 5275.533 ( $d f=$ 496), at the significance level of $p<0.000$. This data is exhibited in table 3 . The conclusion derived from the results was that the variables or questionnaire statements were essentially related, implying that the factor analysis was appropriate for the data set. Furthermore, the KMO value was 0.94 , thus confirming that factor analysis was indeed a suitable procedure that could be used in this study.

After the task of establishing whether factor analysis was appropriate for the study through Bartlett's test of sphericity and the KMO, the next logical task was to determine the number of factors that could be extracted for the study. These factors were extracted utilizing a scree plot.

\subsection{The scree plot method of factor extraction}

Tai (2005:194) defines a scree plot as "a distinct break between the steep slope of factors, with large eigenvalues and a gradual tailing off associated with the rest of the factors." This gradual tailing off is referred to as the scree. In essence, the specific point where the scree begins to tail off is an indication of the actual number of factors appropriate for the study.

The scree plot for this study is illustrated in figure 1. The point of levelling off in the scree is at five factors. The implication was that only five factors could be used in this study. The five factors were named as: participation and budget control, budget planning, motivation, training and development including co-ordination and communication (table 4).

To assign the 38 items in the questionnaire to each of the five extracted factors the Principal Component Analysis (PCA) was utilised. In accordance with the PCA factor, loadings of items with the value of $>0.50$ should be considered to be the threshold for assigning to a factor (Uzoka, Shemi \& Seleka, 2007). Items associated with each factor that were below the threshold were disregarded because they had low factor loadings $(<0.50)$, low commonalities and multiple or unstable loadings (Coolidge, 2006). 
Figure 1: Scree plot with five factors

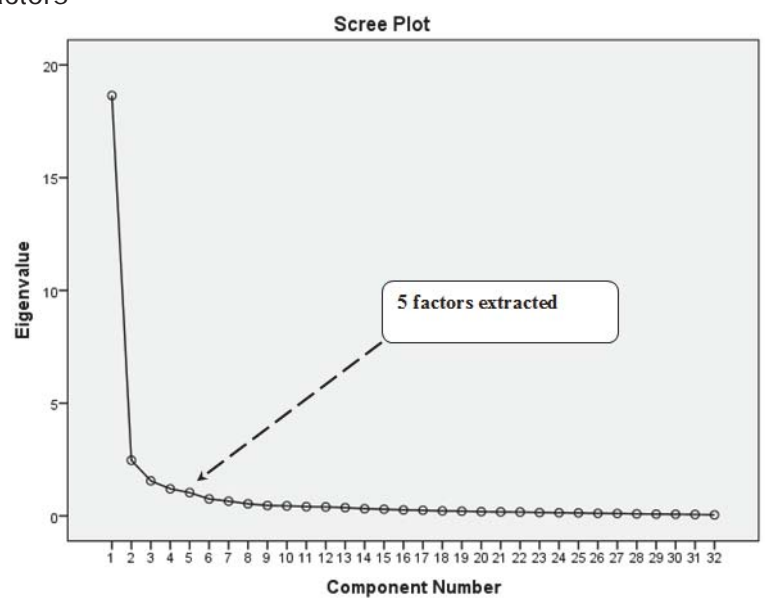

Varimax rotation was utilized to effect maximisation of variance loadings through all the variables (Tabachnick \& Fidel, 2001). Table 4 shows the PCA results for every item per factor. Six items that had low factor loadings below 0.50 and low commonalities were removed. This resulted in 32 items, loading onto 5 factors (Table 4).

\subsection{Discussion}

This study was conducted to identify behavioural factors that contribute to an effective budgeting process. The five identified behavioural factors were participation and budget control, budget planning, motivation, training and development, and co-ordination and communication.

Table 4: Factor loadings

\begin{tabular}{|c|c|c|c|c|c|}
\hline Factor and variable description & 1 & 2 & 3 & 4 & 5 \\
\hline \multicolumn{6}{|l|}{ Factor 1: Participation and budget control } \\
\hline The school principal involves the subordinates in setting the budget objectives & .699 & & & & \\
\hline The school principal involves the parents in setting the budget objectives & 697 & & & & \\
\hline Subordinates participate in decisions on budget alternatives & .716 & & & & \\
\hline The school finance committee prepares the budget annually & .721 & & & & \\
\hline The budget is compared to the income and expenditure on a monthly basis & .792 & & & & \\
\hline The Budget Variance Report is presented to the SGB on a monthly basis & .770 & & & & \\
\hline Bank statements are collected and reconciled on a monthly basis & .733 & & & & \\
\hline Budget control at your school helps measure efficiency in different departments of the school & .618 & & & & \\
\hline Performance targets are set and made known in advance to participants & .739 & & & & \\
\hline Benchmarks are developed to evaluate financial target achievements & .746 & & & & \\
\hline $\begin{array}{l}\text { The previous year's income and expenditure is compared to the current year's income and } \\
\text { expenditure to judge current budget performance }\end{array}$ & .775 & & & & \\
\hline Parents participate in decisions on budget alternatives & .702 & & & & \\
\hline \multicolumn{6}{|l|}{ Factor 2: Budget planning } \\
\hline In our school, the budget helps to plan for the income and expenditure for the next year & & .814 & & & \\
\hline In our school, the budget provides a way of allocating expenditure to different school activities & & .797 & & & \\
\hline $\begin{array}{l}\text { In our school, the budget assists the school to determine the amount required to supplement the } \\
\text { resources provided by the state }\end{array}$ & & .851 & & & \\
\hline In our school, the budget serves as an instrument of controlling spending during the year & & .650 & & & \\
\hline $\begin{array}{l}\text { In our school, the budget assists the school to arrive at a fair and equitable amount of fees to be } \\
\text { charged }\end{array}$ & & .682 & & & \\
\hline \multicolumn{6}{|l|}{ Factor 3: Motivation } \\
\hline The principal rewards educators for achieving budget targets & & & .826 & & \\
\hline The principal is rewarded for achieving budget targets & & & .868 & & \\
\hline The principal is threatened with action if budget objectives are not met & & & .823 & & \\
\hline Budgeting motivates educators to achieve instructional goals & & & .522 & & \\
\hline
\end{tabular}




\begin{tabular}{|c|c|c|c|c|}
\hline Factor 4: Training and development & & & & \\
\hline The school managers undergo skills development in financial management & & & 757 & \\
\hline The school finance committee undergoes skills development in financial management & & & .783 & \\
\hline Educators undergo skills development in financial management & & & 656 & \\
\hline Factor 5: Co-ordination and communication & & & & \\
\hline Communication about budgeting at your school takes place in a top-down approach & & & & .786 \\
\hline Your school issues budget guidelines prior to preparing the budget & & & & .626 \\
\hline Communication about budgeting in your school takes place in a bottom-up approach & & & & .719 \\
\hline Co-ordination among various departments during budget is achieved & & & & 659 \\
\hline Budget plans, policies and constraints are communicated to you via a circular & & & & .735 \\
\hline Eigenvalue $\%$ of variance explained Cumulative $\%$ & \begin{tabular}{|l|l|}
18.64 & 2.46 \\
58.26 & 7.72 \\
58.26 & 65.98 \\
\end{tabular} & \begin{tabular}{|l|}
1.55 \\
4.56 \\
70.54
\end{tabular} & \begin{tabular}{|l|}
1.20 \\
3.75 \\
74.29
\end{tabular} & \begin{tabular}{|l|}
1.03 \\
3.22 \\
77.51 \\
\end{tabular} \\
\hline
\end{tabular}

Extraction method: Principal Component Analysis

Rotation method: Varimax with Kaiser Normalisation

The first factor, participation and budget control, refers to participation of employees and other stakeholders in the budgeting process without imposing decisions on them. Employees are principals, deputy-principals, heads of departments, and educators whereas other stakeholders relate to parents who are involved in the budgeting process through the finance committee and the School Governing Body. Budgeting control denotes the comparison of planned budget and actual budget or the comparison of revenue against expenditure. Table 4 shows that participation and budget control factor accounted for $58.26 \%$ of the variance in item scores with the eigenvalue of 18.64 . The factor affirms that participation of role players in the budgeting process and budget control are imperative preconditions for an effective budgeting process. A participative approach to the budgeting process, also known as self-imposed budgeting, allows all levels of employees in an organisation to work together in the production of a budget (Garrison \& Noreen, 2003). Selfimposed budgeting has been considered to be the effective method of budget preparation (Yuen, 2004). Participative approach to budgeting allows employees the opportunity in fine-tuning the budget plans for an organisation through exchange of information and eventually influencing the budget outcomes (Subramaniam \& Mia, 2001). Additionally, an effective budgeting process has been found to have a built-in budget control in which case the objectives of an organisation are clearly defined in financial terms to allow for measurement of the actual budget against the planned budget. Where unfavourable variances occur corrective action should be taken (Nir \& Miran, 2006).

Factor 2, budget planning, connotes planning for income and establishing the expenditure for a specific financial period. In table 4 the budget planning factor accounted for $7.72 \%$ in the item scores with the eigenvalue of 2.46 . These results confirm the view that an effective budgeting process can be achieved when there is budget planning in schools. Magner et al. (2006) hold the view that budget planning is the design of a desired future, in financial terms, and an effective way of bringing it about and is deemed an effective practice for management in all types of organisations. The budget plans should be based on the corporate objectives (Fruitticher, Stroud, Laster \& Yakhou 2005). Vigario (2005: 230 cautions that budget plans should be so structured that there is reasonably high chance of attaining corporate objectives.

The third factor, motivation, implies that educators, deputy-principals and principals are rewarded for achieving budget objectives. In Table 4 this factor accounted for $4.56 \%$ of the variance in item scores and the eigenvalue of 1.55 . The implication of these values is that an effective budgeting process can only occur when educators, deputy-principals and principals are reinforced for the attainment of budget targets. If there is a joint setting of budget targets by all levels of managers, managerial behaviour can be influenced and managers can be motivated to perform in line with the organisation's objectives (Drudy, 2001). The attainment of the long-term and short-term budget objectives is dependent on employees' understanding of the organisation's goals and acting in such a manner as to meet them. Sometimes managers will attempt to coerce subordinates to achieve budgets by either offering a bonus or threatening to take actions if budget objectives are not met (Vigario, 2005). Rather than being used as a pressure device, the budget should be used as a positive instrument or motivating tool to assist in establishing goals, in measuring operating results, and disclosing areas that are in need of extra effort or attention (Garrison \& Noreen, 2003).

The fourth factor, training and development, involves the skills development of role payers in financial management in order to maximize their participation. This factor accounted for $3.75 \%$ of the variance and recorded an eigenvalue of 1.20. The confirmation resulting from these values is that training and development in aspects of financial management is a requirement for an effective budgeting process in schools. Scott (2001) submits that fully devolved budgets require managers and their subordinates to have financial skills. For this reason, managers including their subordinates must undergo some skills development on financial management so that they are fully conversant with the relevance and 
importance of budgeting and budgetary control system. Empowering all managers on the budgeting process has the potential benefit of enhancing the contribution they make as individuals and as members of a team.

The fifth factor, co-ordination and communication, denotes the creation of an environment that allows for discussions on budget issues. It also means that the budgeting process is carried out in a coordinated way. The factor accounted for $3.22 \%$ of the variance and an eigenvalue of 1.03 . The implication from these results is that co-ordination and communication are indispensable factors for effective budgeting process in schools. Co-ordination is the establishment of the framework in which budget activities are to be performed. Co-ordination refers to the systematisation of interdependent parts into one unit. Co-ordination requires bringing the many functional units of an organisation into a co-ordinated structure and assigning authority and responsibility to individuals (Drudy, 2001). Co-ordination of budget activities is, furthermore, an effort to motivate employees to work together for the good of an organisation (Vigario, 2005). An effective budgeting process requires a high level of involvement in decision-making about budget plans and policies which can only come about if the budget plans and policies are communicated to lower levels of employees. Effective communication requires an organisation structure which reflects the responsibility and the authority of management. Communication should cascade down through this organisational structure. A reverse form of communication should also be considered so that management learns of the concerns of their employees and other relevant stakeholders (Weetman, 2003)

\section{Future Research Opportunities}

The current research aimed at identifying the behavioural factors that are essential for an effective budgeting process in public secondary schools. Future research could focus on comparing the application of the budgeting process between rural and urban schools. Further research could be undertaken to compare the application of the budgeting processes of schools of one province with schools of another province.

\section{Conclusion}

It is apparent from the findings that organisations, including public secondary schools, have to take behavioural factors into serious consideration in their budgeting processes. A budgeting process that is purely quantitative overlooks, if not undermines, the behavioural elements that could assist to optimize resources and maximize the contribution of role players. The more role players are involved in the budgeting process the more the likelihood of full commitment to its implementation. The budgeting process characterized by budget control is effective as it offers financial diagnosis that reveals the extent to which management attains corporate objectives. Budget control provides opportunities for execution of corrective actions in case of deviations from the planned budget.

\section{References}

Andrews, M. (2004). Authority, acceptance, ability and performance-based budgeting reforms. The International Journal of Public Sector Management, 17(4), 332-344.

Coolidge, F.L.2006. Statistics: A gentle introduction. ( $2^{\text {nd }}$ ed).California: Sage Publications, Inc.

De Waal, A.A. (2005). Insight from practice: is your organization ready for beyond budgeting? Measuring Business Excellence, 9(2), 5667.

Dinako management consultants. (2004). Financial Management for Schools. Dinako: Marshalltown.

Drudy, C., (2001). Management Accounting for Business Decisions. ( ${ }^{\text {nd }}$ ed). London: Thomson Learning.

Du Toit, G. S., Neuland, E.W., Oost, E.J \& Begemann, E. (2001). Capital Investment Decisions. Principles and Applications. (2nd ed). Pretoria: Unisa Press.

Dyson, J.R. (2004). Accounting for Non-accounting Students. (6th ed). New York: Prentice Hall Financial Times.

Fruitticher, L., Stroud, N., Laster, J. \& Yakhou, M. (2005). Budget practices case studies. Managerial Auditing Journal, 20 (2), 171-178.

Garrison.R.H. \& Noreen, E.W. (2003). Managerial Accounting. 10 th edition. New York: Irwin, McGraw- Hill.

Hansen, D.R. \& Mowen, M.M. (2000). Cost Management: accounting and control. (3rd ed). Toronto: South-Western College Publishing.

Hansen, D.R. \& Mowen, M.M. (2000). Management Accounting. (5th ed). Toronto: South-Western College Publishing.

Hassen, M., (2011). Recording and Evaluating Costs and Revenues. Johannesburg: AAT(SA)

Horngren, C.T., Sundem, G.L. \& Stratton, W.O. (2002). Introduction to Management Accounting. (12 thed). New Jersey: Prentice Hall Inc.

James, W. (2006). A processual view of institutional change of the budget process within an Australian government-owned electricity corporation. International Journal of Public Sector, 19(1), 5-39.

Leedy, P.D \& Ormrod, J.E. (2001). Practical Research: planning and design. (7thed). New Jersey: Merrill Prentice-Hall.

Lombaard,C., Van der Merwe, L., Kele, T. \& Mouton, S. (2011). Elementary Statistics for Business and Economics. South 
Africa:Heinemann Publishers (Pty) Ltd

Lucey, T. (2002). Costing. (6th ed). London: Continuum.

Luecke, R. (2002). Harvard Business Essentials: Finance for Managers. Boston:

Harvard Business School Press.

Magner, N.R., Johnson, G.G., Little, H.T. Staley, A.B. \& Welker, R.B. (2006). The case of fair budgetary procedures. Managerial Auditing Journal, 21(4), 408-419.

Manoharan, P.K. (2010).Research Methodology. New Delhi: APH Publishing Corporation.

McLeary, F. (1999). Accounting and its Business Environment. (5th ed). Kenwyn:

Juta \& Co Ltd.

Moore, N. (1999). Forecasting Budgets: 25 keys to successful planning. London: Lebhar Friedman Books.

Nir, A.E. \& Miran, M. (2006).The equity consequences of school-based management. International Journal of Education, 20 (2), 116126.

Scott, G. (2001).Getting the fuzzy end of the lollipop: the problems with devolved budgets in further education colleges. International Journal of Educational Management, 15(5),252-257.

Subramaniam, N. \& Mia, L. (2001). The relation between decentralized structure, budgetary participation and organizational commitment (The moderating role of manager's value orientation towards innovation). Accounting, Auditing \& Accountability Journal, 14(1),1229.

Tai,S.H.C. (2005). Shopping styles of working Chinese females. Journal of Retailing and Consumer Services,12(3), 191-203

Tabachnick. B.G. \& Fiedel, L.S. (2001). Using Multivariate Statistics (4th ed.). New York: Harper Collins College Publishers.

Uzoka, F. M. E., Shemi, A. P. \& Seleka, G. G. (2007). Behavioural influences of E-Commerce adoption in a developing country context. Electronic Journal of Information Systems in Developing Countries, 31(4),1-15.

Van Rensburburg, M., Ambe, CM., Evangelou,O., Govender,B., Koortzen, PJ., \& Ziemerink, J.E.E. (2008).Cost and Management Accounting. (2nd ed). Pretoria: Van Schaick Publishers.

Vigario, A.A. (2005). Managerial Accounting. (3rd ed). Pietermaritzburg: Interpak Books.

Weetman, P. (2003). Management Accounting: An introduction. (3rd ed). London:

Pitman Publishing.

Williams,B., Onsman, A. \& Brown, T.(2010). Exploratory factory analysis: A five step guide for novices. Journal of Emergency Primary Health Care,8(3),1-3.

Yuen, D. (2004). Goal characteristics, communication and reward systems, and managerial propensity to create budgetary slack. Managerial Auditing Journal, 19(4), 517-532. 